\title{
Crohn's disease in Nottingham: A search for time-space clustering
}

\author{
D. S. Miller, ANDREA KeIghley, P. G. SMith, A. O. HUGHES, AND \\ M. J. S. LANGMAN \\ From the Departments of Community Health and Therapeutics, Medical School, Nottingham University, \\ and the DHSS Cancer Epidemiology and Clinical Trials Unit, Oxford University
}

SUMMARY All cases of Crohn's disease in the Nottingham area were ascertained and the date and place of domicile and work at the time of onset of symptoms noted. Applying the Knox and Pike and Smith tests for clustering of patients in time and space, no significant results were observed.

Further analysis of differences in time-space clustering between a group of patients and matched controls is in hand.

Lesions resembling those of Crohn's disease in man have been produced by inoculation of Crohn's disease tissue into mice and rabbits. This and further evidence that passage to a second set of animals can be demonstrated suggests that a transmissible agent could be responsible (Mitchell and Rees, 1970 and 1971; Cave and Mitchell, 1974). It therefore seemed reasonable to attempt to explore the possible infectious nature of Crohn's disease epidemiologically, although attempts to confirm transmission by further animal studies have been unsuccessful (Bolton, Owen, Heatley, Williams, and Hughes, 1973).

Epidemiological evidence of the contagious or infectious nature of a disease may be provided by the observation of 'time-space clustering' of cases of the disease. Knox was the first to suggest a statistical technique for demonstrating clustering (Knox, 1963 and 1964), proposing that for all patients with onset of disease in a defined area and time period, the dates and places of onset be compared for all possible pairs of patients. Significant numbers of such pairs being 'close' in both time and space provides evidence of clustering, and by this method Knox (1964) showed clustering of cases of leukaemia in Northumberland and Durham, and Pike, Williams, and Wright (1967) demonstrated very significant clustering of Burkitt's lymphoma in Uganda. A disadvantage of this Knox model is that it is applicable only to diseases with short latent periods when an association between time and place at the onset of disease would be expected in relation to transmission of that disease. Pike and Smith have generalized

Received for publication 24 March 1975.
Knox's method (Pike and Smith, 1968) so that it might be applied to diseases with possibly long latent periods. The method involves postulating for each patient a period of 'susceptibility' when he is assumed to have 'caught' the disease, and a period of 'infectivity' when he could transmit the disease. The patients' movements during these times, eg, places of residence, must also be defined. All possible pairs of patients are examined to determine the number of pairs in the 'right' place at the 'right' time for transmission of disease to have occurred, ie, one person's time and area of susceptibility must overlap with another's time and area of infectivity. Pike and Smith have derived formulae for the expectation and variance of the number of such links, assuming no association between times and places of susceptibility and infectivity, and thus the statistical significance of observed links may be assessed.

We have applied both the Knox and Pike and Smith generalized method to Crohn's disease in the Nottingham area to look for evidence of an infectious aetiology.

\section{Method}

All patients diagnosed as having Crohn's disease between 1958 and 1973 and living in the catchment area of the two Nottingham district general hospitals were sought. The final area covered most of south Nottinghamshire and parts of south-east Derbyshire. The methods used to ascertain and verify the 260 cases have previously been described (Miller, Keighley, and Langman, 1974). All patients, or their surviving relatives, who lived or worked in this area 


\begin{tabular}{|c|c|c|c|c|c|c|c|c|c|}
\hline \multirow{2}{*}{$\begin{array}{l}\text { Time between } \\
\text { Dates of Onset } \\
(\mathrm{mth})\end{array}$} & \multicolumn{8}{|c|}{ Distance between Places of Residence at Time of Onset ( $\mathrm{km})$} & \multirow[t]{2}{*}{ Total } \\
\hline & $0-$ & $0.25-$ & $0.5-$ & $0.75-$ & $1-$ & $1.5-$ & $2-$ & $2.5+$ & \\
\hline $0-$ & $\begin{array}{l}10 \\
2 \mathrm{E}\end{array}$ & $\begin{array}{l}2 \\
3\end{array}$ & $\begin{array}{l}3 \\
5\end{array}$ & $\begin{array}{l}2 \\
5\end{array}$ & $\begin{array}{l}11 \\
13\end{array}$ & $\begin{array}{l}11 \\
18\end{array}$ & $\begin{array}{l}17 \\
18\end{array}$ & $\begin{array}{l}866 \\
849\end{array}$ & 913 \\
\hline $6-$ & $\begin{array}{l}0 \\
2\end{array}$ & $\begin{array}{l}4 \\
3\end{array}$ & $\begin{array}{l}3 \\
5\end{array}$ & $\begin{array}{l}3 \\
5\end{array}$ & $\begin{array}{l}13 \\
13\end{array}$ & $\begin{array}{l}11 \\
18\end{array}$ & $\begin{array}{l}20 \\
18\end{array}$ & $\begin{array}{l}850 \\
841\end{array}$ & 904 \\
\hline $12-$ & $\begin{array}{l}1 \\
2\end{array}$ & $\begin{array}{l}4 \\
3\end{array}$ & $\begin{array}{l}8 \\
5\end{array}$ & $\begin{array}{l}4 \\
5\end{array}$ & $\begin{array}{l}17 \\
12\end{array}$ & $\begin{array}{l}13 \\
17\end{array}$ & $\begin{array}{l}11 \\
17\end{array}$ & $\begin{array}{l}803 \\
801\end{array}$ & 861 \\
\hline $18-$ & $\begin{array}{l}3 \\
2\end{array}$ & $\begin{array}{l}1 \\
3\end{array}$ & $\begin{array}{l}6 \\
5\end{array}$ & $\begin{array}{l}0 \\
5\end{array}$ & $\begin{array}{r}7 \\
12\end{array}$ & $\begin{array}{l}20 \\
16\end{array}$ & $\begin{array}{l}19 \\
17\end{array}$ & $\begin{array}{l}781 \\
779\end{array}$ & 837 \\
\hline $24-$ & $\begin{array}{l}3 \\
3\end{array}$ & $\begin{array}{l}2 \\
5\end{array}$ & $\begin{array}{r}10 \\
9\end{array}$ & $\begin{array}{r}10 \\
8\end{array}$ & $\begin{array}{l}30 \\
21\end{array}$ & $\begin{array}{l}38 \\
29\end{array}$ & $\begin{array}{l}38 \\
30\end{array}$ & $\begin{array}{l}1370 \\
1397\end{array}$ & 1507 \\
\hline $36+$ & $\begin{array}{l}13 \\
12\end{array}$ & $\begin{array}{l}22 \\
20\end{array}$ & $\begin{array}{l}40 \\
40\end{array}$ & $\begin{array}{l}46 \\
37\end{array}$ & $\begin{array}{l}83 \\
92\end{array}$ & $\begin{array}{l}134 \\
129\end{array}$ & $\begin{array}{l}125 \\
131\end{array}$ & $\begin{array}{l}6149 \\
6152\end{array}$ & 6612 \\
\hline Total & 21 & 35 & 70 & 65 & 161 & 227 & 230 & 10819 & 11628 \\
\hline
\end{tabular}

Table I Analysis of all pairs of cases by home address and date of onset of disease (Knox's method)

$\mathbf{O}=$ observed number of pairs, $\mathrm{E}=$ expected number of pairs

were interviewed to determine the dates of onset and diagnosis of the disease, and all addresses from five years before the onset of symptoms until 31 December 1972 for home, schools, and occupations. All addresses were given from ordnance survey maps grid coordinates to within 100 metres. By analogy with the methods of infectious disease epidemiology we examined our familial data (11 cases in five families) for clues as to the possible latent period of the disease. However, the differences between times of onset ranged from six months to over seven years, and suggested no obvious periods to be used in the model. A variety of different 'critical' times and distances were thus examined to detect evidence of clustering.

\section{Results}

Table I shows the number of pairs of cases whose onset dates were within the specified times of each other, and whose places of residence were within the specified distances of each other (observed: ' $O$ '). The expected number of pairs, calculated assuming the absence of time-space clustering, is shown also (expected: 'E'). All results have been condensed and figures rounded for publication, but tests of signifi-

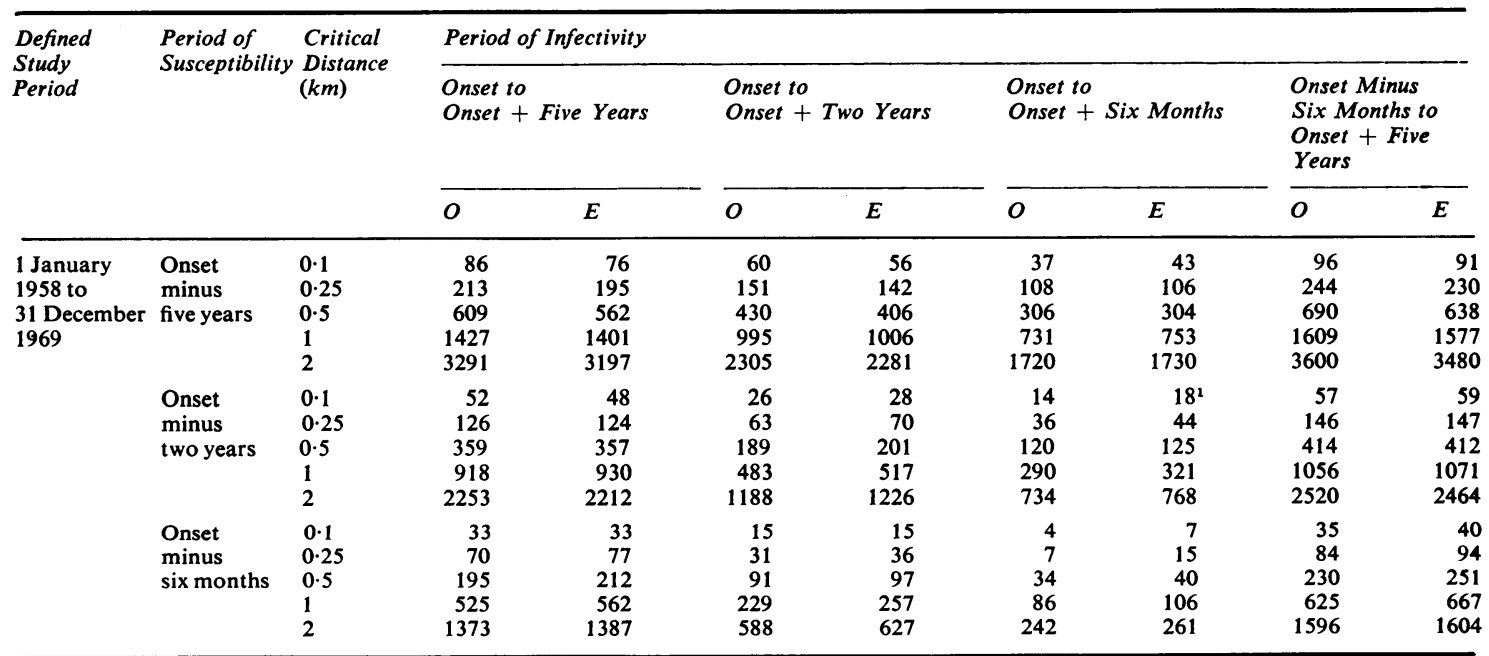

Table II Analysis of all pairs by home address and date of onset of disease in cases diagnosed from 1 January 1958 to 31 December 1972 (Pike and Smith's method)

$\mathbf{O}=$ observed number of pairs, $\mathrm{E}=$ expected number of pairs

Variances are respectively: $12 \cdot 4 ; 30 \cdot 75 ; 87 \cdot 7 ; 239 \cdot 23 ; 620 \cdot 61$ 


\begin{tabular}{|c|c|c|c|c|c|c|c|c|c|c|}
\hline \multirow{3}{*}{$\begin{array}{l}\text { Defined } \\
\text { Study } \\
\text { Period }\end{array}$} & \multirow{3}{*}{$\begin{array}{l}\text { Period of } \\
\text { Susceptibility }\end{array}$} & \multirow{3}{*}{$\begin{array}{l}\text { Critical } \\
\text { Distance } \\
(\mathrm{km})\end{array}$} & \multicolumn{8}{|c|}{ Period of Infectivity } \\
\hline & & & \multicolumn{2}{|c|}{$\begin{array}{l}\text { Onset to } \\
\text { Onset }+ \text { Five Years }\end{array}$} & \multicolumn{2}{|c|}{$\begin{array}{l}\text { Onset to } \\
\text { Onset }+ \text { Two Years }\end{array}$} & \multicolumn{2}{|c|}{$\begin{array}{l}\text { Onset to } \\
\text { Onset }+ \text { Six Months }\end{array}$} & \multicolumn{2}{|c|}{$\begin{array}{l}\text { Onset Minus } \\
\text { Six Months to } \\
\text { Onset + Five } \\
\text { Years }\end{array}$} \\
\hline & & & $O$ & $E$ & $O$ & $E$ & $O$ & $E$ & $O$ & $E$ \\
\hline
\end{tabular}

Table III Analysis of all pairs by home address and date of onset of disease in cases diagnosed from 1 January 1958 to 31 December 1972 (Pike and Smith's method)

$\mathbf{O}=$ observed number of pairs, $\mathbf{E}=$ expected number of pairs

cance were calculated on the original figures. The 260 cases have been reduced to 153 in this table by specifying dates of diagnosis before December 1972, dates of onset after January 1958 and before December 1969, and area of residence as defined above. There is no evidence of an excess of observed pairs in any cell of the table. A similar computation based upon occupational addresses also produced negative findings.

Tables II and III show the analysis of the data by the method of Pike and Smith, using cases diagnosed between 1 January 1958 and 31 December 1972. For the purposes of this analysis, the study period has been defined, with regard to date of onset, from 1 January 1958 to 31 December 1969 (table II) or to 31 December 1967 (table III). This time restriction results in a rejection upon date criteria for both infectivity and susceptibility, and the majority of patients included will have both infective and susceptible time periods.

The postulated periods of infectivity and susceptibility are shown in the tables, the latter, it should be stressed, being the time when the patient was not only susceptible but also became infected. For each patient pair, we determined whether these two times overlapped, and if any of their places of residence during these times were within the critical distances of each other. Those used were $0 \cdot 1,0 \cdot 25,0 \cdot 5,1 \cdot 0$, and $2.0 \mathrm{~km}$. As before observed pairs $(\mathrm{O})$ are shown against expected numbers of pairs $(\mathrm{E})$.

An approximate test of significance for comparing $O$ and $E$ values on these tables is provided by assuming the $O$ values to be from a Poissonian distribution with mean equal to the $\mathrm{E}$ value. The assumption is supported by the variance values, calculated for a typical cell appropriately marked (table II), and in no instance do the number of observed links approach a statistically significant excess over the expected number.

\section{Discussion}

No causal mechanism for Crohn's disease has yet been established. By analogy of the symptoms with those of infective diarrhoea, much time has been devoted to the search for an invading organism, but without success. In a second approach, the lymphatic dilatation noted by pathologists and the involvement of mesenteric lymph nodes in the inflammatory process suggested, as a cause, an agent causing obstruction to lymph flow. Thirdly, since certain features of Crohn's disease are held in common with ulcerative colitis, and patients with either disease occasionally show a family history of either or both conditions, and of certain other rare conditions such as ankylosing spondylitis, it has been suggested that genetic activity of a multifactorial kind is partly responsible for the occurrence of Crohn's disease (McConnell, 1971). The similarity of the histological picture and the possible depression of cellular immunity in sarcoidosis and Crohn's disease (Verrier-Jones, Housley, Ashurst, and Hawkins, 1969) led to experimental attempts at transmission of a causative agent to mice and rabbits in both diseases (Mitchell and Rees, 1969; Cave, Mitchell, Kane, and Brooke, 1973). This work led us to search for epidemiological evidence of contagion among patients with Crohn's disease using tests for time-space interaction. The findings give no support to the contagion hypothesis. However, negative findings do not rule out the possibility of a transmissible agent in the disease. We have stressed that the Knox method may not be appropriate for diseases with long latent periods, and the Pike and Smith method only partly overcomes this problem, since one must assume a similar latent period for each patient, but if the latent period is long it is likely to vary in duration. Tables II and III have only examined a limited number of time periods, and we may have chosen the wrong ones, though there 
are no data on which to base any such choice. It is possible to find situations where the tests will not detect clustering of a disease which is thought to be infectious, because, for example, there is probably a carrier state (Nye and Spicer, 1972). Thus, although our findings lend no support to the infection hypothesis for Crohn's disease, they should not be taken as strong evidence against it.

We are now attempting to analyse differences between patients with Crohn's disease and matched controls with respect to their places of residence and social background, in the hope that more refined comparisons will be possible.

It is a pleasure to record our thanks to the consultants and general practitioners who sent us information about patients, and to Miss J. R. Sibley.

This research was supported by a grant from the Medical Research Council.

\section{References}

Bolton, P. M., Owen, E., Heatley, R. V., Williams, W. J., and Hughes, L. E. (1973). Negative findings in laboratory animals for a transmissible agent in Crohn's disease. Lancet, 2, 11221124 .

Cave, D. R., and Mitchell, D. N. (1974). An experimental animal model of Crohn's disease. (Abstr.), Gut, 15, 345.

Cave, D. R., Mitchell, D. N., Kane, S. P., and Brooke, B. N. (1973). Further animal evidence of a transmissible agent in Crohn's disease. Lancet, 2, 1120-1122.

Knox, G. (1963). Detection of low intensity epidemicity application to cleft lip and palate. Brit. J. Prev. soc. Med., 17, 121127.

Knox, G. (1964a). Detection of space-time interactions. Appl. Statist., 13, 25-30.

Knox, G. (1964b). Epidemiology of childhood leukaemia in Northumberland and Durham. Brit. J. prev. soc. Med., 18, 17-24.

McConnell, R. B. (1971). Genetic factors in Crohn's disease. In Regional Enteritis (Crohn's Disease): 5th Skandia International Symposium, 1970, pp. 220-232. Nordiska Bokhandelns Forlag, Stockholm.

Miller, D. S., Keighley, A. C., and Langman, M. J. S. (1974). Changing patterns in epidemiology of Crohn's disease. Lancet, 2 , 691-693.

Mitchell, D. N., and Rees, R. J. W. (1970). Agent transmissible from Crohn's disease tissue. Lancet, 2, 168-171.

Mitchell, D. N., and Rees, R. J. W. (1971). Sarcoidosis and Crohn's disease. Proc. roy. Soc. Med., 64, 944-945.

Mitchell, D. N., and Rees, R. J. W. (1969). Transmissible agent from sarcoid tissue. Lancet, 2, 81-84.

Nye, F., Jr., and Spicer, C. C. (1972). Space-time clustering in infectious mononucleosis. Brit.J. prev, soc. Med. 26, 257-258.

Pike, M. C., and Smith, P. G. (1968). Disease clustering: a generalization of Knox's approach to the detection of space-time interactions. Biometrics, 24, 541-556.

Pike, M. C., Williams, E. H., and Wright, B. (1967). Burkitt's tumour in the West Nile District of Uganda 1961-1965. Brit. med.J., 2, 395-399.

Verrier-Jones, J., Housley, J., Ashurst, P. M., and Hawkins, C. F. (1969). Development of delayed hypersensitivity to dinitrochlorobenzene in patients with Crohn's disease. Gut, 10, $52-56$. 